\title{
The Accounting Analysis of Banking Company: The Case of CAM
}

\author{
Miguel Angel Perez Benedito \\ Accounting Department of Economy Faculty, Valencia University, Valencia, Spain \\ Email: miguel.a.perez@uv.es
}

Received 12 January 2015; accepted 30 January 2015; published 5 February 2015

Copyright (C) 2015 by author and Scientific Research Publishing Inc.

This work is licensed under the Creative Commons Attribution International License (CC BY). http://creativecommons.org/licenses/by/4.0/

(c) (i) Open Access

\begin{abstract}
The measure of management risk has been a constant in Economy in the recent past. This issue is present on any kind of economic or financial activity. The solution adopted for international authorities, increasing liquidity of financial market and generating new indicators to support making decisions, means the continuity of applying the monetary theory as general criteria to solve the actual crisis. In this labyrinth, the manuscript uses the Accounting Methodology of Edgeworth's Box as a new methodology to measure the management of Banking Companies and analyzes the acquisition of the CAM and Bank Sabadell, two Spanish banking companies. Finally, the manuscript analyzes the financial crisis in Spain through the behavior of listed banking companies in IBEX 35. The manuscript concludes that accounting can explain equilibrium in economy, and it only needs to know how they can be measured properly.
\end{abstract}

\section{Keywords}

Accounting Analysis, New Methodology, Banking Companies

\section{Introduction}

The management measures of bank don't have enough references from the accounting analysis. Financial indicators, as well as the opinion of stock market, have measured their activity on financial literature [1]-[4]. These measures are made on considering the internal validity of methods to value and estimate, and the new research comes to adjust variables to such methods. New tendencies as differences-in-differences [5]-[8] or accurate methods [9]-[11] pursued achieve a conclusion more approached to real situations, but these method cannot ever be applied as a general criteria.

The alternative of financial authority is to give trust to stakeholders on economic and financial activity, because this change of methodology is not consolidated yet to explain perturbations of markets currently. There- 
fore, the authorities of stock market have begun a strategy to give to know the management activities of the listed companies on a report attached with prospective projections and other non-financial indicators [12]-[14]. The new methodology has this tendency. In order to analyze the banking companies, this manuscript first explains the new accounting methodology. Secondly, the manuscript presents the application of this methodology on a bank company to explain its behavior. This banking company got in bankruptcy in 2010 and another banking company absorbed it, so the manuscript goes on analyzing the evolution of the second company, the absorbent company. Finally, the manuscript has conclusions where its author describes the characteristics of this study made by Accounting Methodology of Edgeworth’s Box.

\section{Ease of Use}

The Accounting Methodology of Edgeworth's Box (AMEB) has its main utility on the explanatory capacity of behavior of company. According to previous work of Perez [15], a company has economic (ET) and financial (FT) transactions. These two kinds of transactions change economic values for financial or monetary values. An economic transaction negative (ET -) is a purchase or acquisitions goods from economic market and an economic transaction positive $(\mathrm{ET}+)$ represents a sale or alienation of company goods to the same economic market. Both kinds of transactions achieve a financial position on financial market. When a company does a negative economic transaction (ET-), the company gets a credit from financial market named negative financial transaction (FT -) . On the contrary, when a company does an ET+, it has compensation on financial market named positive financial transaction $(\mathrm{FT}+)$ and gives credit to financial market. These transformations recorded in an accounting system by method of double entry and the criteria of accounting accrual explain the same result, as expression 1.

$$
(\mathrm{ET}+)-(\mathrm{ET}-)=(\mathrm{FT}+)-(\mathrm{FT}-)
$$

The differences between economic transactions, on the left side of expression 1, are the operative result (OR) and the values of assets unsold on economic market at the end of an accounting exercise. These values of assets unsold are the interannual variations of assets on a balance sheet, and it can be positive or negative $(\Delta \mathrm{A})$. The result of differences of financial transactions is the same as the result of economic transactions from a financial vision. The financial result of FTs are the monetary saving (MS) and the value variation of financial positions $(\Delta \mathrm{F})$, which are adopted for a company by financial activity. All these variations are got from financial statements and the expression 2 represents these results.

$$
\mathrm{OR}-\Delta \mathrm{A}=\mathrm{MS}-\Delta \mathrm{F}
$$

The expression 2 can be obtained from financial statements of banking company. Table 1 measures the financial position adopted for a banking company according expression 2 .

The information obtained from database Orbis is transformed in the next table after Table 2, in which is the adjustment of accounting variables to obtain the financial position of banking company named Caja de Ahorros del Mediterraneo (CAM).

The philosophy to building Table 2 is to consider the financial and economic position of a banking company. So that, the $\Delta \mathrm{F}$ variable is the net financial position when company does compensations among their financial positions supported on financial instruments, either as accounting assets as accounting liabilities. The $\Delta \mathrm{A}$ variable is the increase of economic assets in two years, and they are assets to banking companies. They represent the counterparty of financial positions on the banking activity. The OR variable is an accounting cash flow on activity for this kind of companies. Therefore, it represents the real result for the real transaction on an economic market, and it is adjusted with accounts that do not represent any real transactions. Finally, the MS variable is the liquidity monetary that banking company have obligation to return to the financial market or to depositors. Table 3 presents variation of variables of expression 2 on company CAM.

The application of general equation (GE) of expression 2 can give negative results, which must be adjusted by several transformations up to get a positive value, as it can see in Table 3 for 2009 and 2005. The aim pursued is get a relative position into an Edgeworth's box, which must explain the result of company activity in a year. However, it must take on account that all transformations will be for all observations, because they will allow analyzing the general activity of company along of a period of study. These transformations must explain annual equilibriums of company in an Edgeworth's box.

According to the above paragraph, Table 4 has transformed the values of banking company of CAM. The 
Table 1. Variation of accounting variables on AMBE.

\begin{tabular}{|c|c|}
\hline Accounting Variables of Financial Statements & Variables of Expression 2 (a) \\
\hline \multicolumn{2}{|l|}{ Assets } \\
\hline Loans & $\mathrm{L}=\mathrm{A}-\mathrm{B}$ \\
\hline Gross loans & A \\
\hline Less: reserves for impaired loans/NPLs & $\mathrm{B}$ \\
\hline Other earning assets & $\mathrm{OEA}=\mathrm{C}+\mathrm{D}+\mathrm{E}+\mathrm{F}$ \\
\hline Loans and advances to banks & $\mathrm{C}$ \\
\hline Derivatives & $\mathrm{D}$ \\
\hline Other securities & $\mathrm{E}$ \\
\hline Remaining earning assets & F \\
\hline Total earning assets & $\Delta \mathrm{F}(+)=\mathrm{L}+\mathrm{OEA}$ \\
\hline Fixed assets & $\Delta \mathrm{A}(+)$ \\
\hline Non-earning assets & $\Delta \mathrm{A}(+)$ \\
\hline \multicolumn{2}{|l|}{ Liabilities \& Equity } \\
\hline Deposits \& short term funding & $\mathrm{D}=\mathrm{TCD}+\mathrm{DFB}+\mathrm{ODB}$ \\
\hline Total customer deposits & TCD \\
\hline Deposits from banks & DFB \\
\hline Other deposits and short-term borrowings & ODB \\
\hline Other interest bearing liabilities & $\mathrm{OI}=\mathrm{DE}+\mathrm{TL}+\mathrm{LTF}$ \\
\hline Derivatives & $\mathrm{DE}$ \\
\hline Trading liabilities & TL \\
\hline Long term funding & LTF \\
\hline Other (non-interest bearing) & $\mathrm{ONIB}=\mathrm{LOR}+\mathrm{OtR}+\mathrm{E}$ \\
\hline Loan loss reserves & LOR \\
\hline Other reserves & OtR \\
\hline Total liabilities & $\Delta \mathrm{F}(-)=\mathrm{D}+\mathrm{OI}+\mathrm{ONIB}$ \\
\hline Equity & $\Delta \mathrm{F}(-)$ \\
\hline \multicolumn{2}{|l|}{ Profit \& Loss Account } \\
\hline Loan loss provisions & $\mathrm{OR}(+)$ \\
\hline Net income & $\mathrm{OR}(+)$ \\
\hline
\end{tabular}

a. The variable of expression 2 has positive or negative symbol and it is the effect on the last value of variable on expression 2.

transformation is made by selecting the higher negative value of variables in Table 3 . This negative value is multiplied by (-2) and added to all values of a period. It allows distributing all observations with equity along of an axis. In order to aim these transformations, the highest negative value in Table 3 is 3176.6116. This negative value multiplies by (-2) is 6353.223,249, and the result to add this origin change on all variables of Table 3 is in Table 4.

Table 4 presents all transformations of observations. They are positives and equitably distributed, as it can be seen on value of $\Delta \mathrm{F}$ variable of the 2009 year of Table 3 in Table 4 . Its relative position does not change.

The next step of this MAEB is to include observations in Edgeworth's box. Considering there are two subjects, assets and liabilities of a balance sheet, which distribute equally their rents among economic and financial goods of the expression 2, then there will be an equilibrium. This equilibrium can be analyzed in an Edge- 
Table 2. Accounting variables on AMBE.

\begin{tabular}{cccc}
\hline Accounting Variables of Financial Statements & Variables of Expression 2 (a) & 2010 (a) & 2009 (a) \\
\hline Financial position & $\Delta \mathrm{F}=\Delta \mathrm{F}(+)-\Delta \mathrm{F}(-)(\mathrm{b})$ & 43596.793 & 40890.434 \\
Financial assets & & 90264.843 & 100073.04 \\
Total earning assets & $\Delta \mathrm{F}(+)=\mathrm{L}+\mathrm{OEA}$ & $90,264,843$ & 100073.04 \\
Liabilities \& equity & & 46668.05 & 59182.601 \\
Other (non-interest bearing) & ONIB = LOR + OtR + E & 37367.114 & 47880.803 \\
Loan loss reserves & LOR & 5323.1285 & 5441.1477 \\
Other reserves & OtR & 95.05348 & 69.436939 \\
Total liabilities & $\Delta \mathrm{F}(-)=\mathrm{D}+\mathrm{OI}+\mathrm{ONIB}$ & 445.58825 & 308.5766 \\
Equity & $\Delta \mathrm{F}(-)$ & 3437.1659 & 5482.637 \\
Economic assets & $\Delta \mathrm{A} \mathrm{(b)}$ & 9305.2143 & 8738.5379 \\
Fixed assets & $\Delta \mathrm{A}(+)$ & 1187.968 & 1295.8201 \\
Non-earning assets & $\Delta \mathrm{A}(+)$ & $81,172,463$ & $74,427,179$ \\
Saving monetary & $\mathrm{D}=\mathrm{MS}(\mathrm{b})$ & 52902.007 & 49628.972 \\
Deposits \& short term funding & $\mathrm{D}=\mathrm{TCD}+\mathrm{DFB}+\mathrm{ODB}$ & 52902.007 & 49628.972 \\
Profit \& loss account & $\mathrm{OR}(\mathrm{b})$ & 593.44922 & 1601.8036 \\
Loan loss provisions & $\mathrm{OR}(+)$ & 266.97862 & 1219.4682 \\
Net income & $\mathrm{OR}(+)$ & 326.4706 & 382.33534 \\
\hline
\end{tabular}

a. The annual values of accounting variable from database ORBIS; b. The variables of expression 2.

Table 3. Accounting variables of general equation on expression 2.

\begin{tabular}{cccccc}
\hline $\begin{array}{c}\text { Accounting Variables of } \\
\text { Financial Statements }\end{array}$ & Variables of Expression 2 & 2010 & 2009 & 2004 & 2002 \\
\hline Financial position & $\Delta \mathrm{F}$ & 2706.3593 & -3176.6116 & -601.21277 & 4281.0673 \\
Economic assets & $\Delta \mathrm{A}$ & 566.67632 & 3096.4497 & -286.19846 & 271.0277 \\
& Sum assets & 3273.0356 & -80.161877 & -887.41123 & 4552.095 \\
Saving monetary & MS & 2679.5864 & -1681.9655 & -1465.8202 & 4234.5481 \\
Acconting cash flow & OR & 593.44922 & 1601.8036 & 578.40902 & 317.54689 \\
& Sum liabilities & 3273.0356 & -80.161877 & -887.41123 & 4552.095 \\
\hline
\end{tabular}

Table 4. Transformations of accounting variables of general equation on expression 2.

\begin{tabular}{cccccc}
\hline $\begin{array}{c}\text { Accounting Variables of } \\
\text { Financial Statements }\end{array}$ & Variables of Expression 2 & 2010 & 2009 & 2004 \\
\hline Financial position & $\Delta \mathrm{F}$ & 9059.5825 & 3176.6116 (a) & 13302.384 & 10634.291 \\
Economic assets & $\Delta \mathrm{A}$ & 6919.8996 & 9449.673 & 6831.0408 & 6624.2509 \\
& Sum assets & 15979.482 & 12626.285 & 20133.425 \\
Saving monetary & MS & 9032.8096 & 4671.2578 & 15615.085 \\
Accounting cash flow & OR & 6946.6725 & 7955.0268 & 7844.6071 & 6878.177 \\
& Sum liabilities & 15979.482 & 12626.285 & 23459.692 & 20133.425 \\
\hline
\end{tabular}

a. The transformation of observation of Table 3 (-3176.6116) do not change its relative position among all variables.

worth's box if all values take the same reference each year. This reference is the 100 value for total assets and total liabilities on each year of a balance sheet. Thereby, each value of each year can take an annual relative position, which will be compared among other annual observations. Table 5 presents the last transformation to get the incorporation of annual observations in an Edgeworth's box. 
Table 5. The observation in an Edgeworth’s box to Banking Company CAM.

\begin{tabular}{cccccc}
\hline $\begin{array}{c}\text { Accounting Variables of } \\
\text { Financial Statements }\end{array}$ & $\begin{array}{c}\text { Variables of } \\
\text { Expression 2 }\end{array}$ & 2010 & 2009 & 2004 & 2002 \\
\hline Financial position & $\Delta \mathrm{F}$ & $56.70 \%$ & $25.16 \%$ & $66.07 \%$ & $61.62 \%$ \\
Economic assets & $\Delta \mathrm{A}$ & $43.30 \%$ & $74.84 \%$ & $33.93 \%$ & $38.38 \%$ \\
& Sum assets & $100.00 \%$ & $100.00 \%$ & $100.00 \%$ & $100.00 \%$ \\
Saving monetary & MS & $56.53 \%$ & $37.00 \%$ & $65.84 \%$ & $61.35 \%$ \\
Acconting cash flow & OR & $43.47 \%$ & $63.00 \%$ & $34.16 \%$ & $38.65 \%$ \\
& Sum liabilities & $100.00 \%$ & $100.00 \%$ & $100.00 \%$ & $100.00 \%$ \\
\hline
\end{tabular}

\section{The Case of Caja De Ahorros Del Mediterraneo (CAM)}

The financial position of Banking Company CAM in an Edgeworth's box shows in Figure 1. It is a natural financial position to companies, and observations in Figure 2 are rotations of observations of Edgeworth's box of Figure 1. The Edgeworth's box allows showing differences between adopted positions for banking companies. In this box, the results of economic and financial transaction are on primary (MS) and secondary (OR) $x$-axes. It allows contrasting the trust of client on bank. The risk of management can be measured by the contrast between variations of economic $(\Delta \mathrm{A})$ and financial $(\Delta \mathrm{F})$ goods of company on primary and secondary $y$ axes, respectively.

To measure the observations in Edgeworth's box, there are two indicators named $L$ and $G$. The $L$ indicator is the expression 3 and the $G$ indicator is the expression 4. These two indicators have respective financial and economic significances.

$$
L=\frac{\Delta \mathrm{F}}{\mathrm{OR}}-\frac{\Delta \mathrm{A}}{\mathrm{MS}}
$$

The ratio, $\Delta \mathrm{F}$ divided by $\mathrm{OR}$, measures how many times the $\Delta \mathrm{F}$ can pay the $\mathrm{OR}$. That's to say, how many times a financial position guarantees the management result, and thus stakeholders have trust on this kind of management because it guarantees the transformation of an economic value to a monetary value. The relation between $\triangle \mathrm{A}$ and MS explains how many times the MS is materialized on $\Delta \mathrm{A}$, and when its value is less than one, the client have a high level of trust on management of banking company, because company has got more liquidity than economic goods as result of their transactions in a period. According to differences of the $L$ indicator, when $L$ is positive, the company has guaranty on its management activity and gets credit from financial market.

$$
G=\frac{\Delta \mathrm{A}}{\mathrm{OR}}-\frac{\Delta \mathrm{F}}{\mathrm{MS}}
$$

To explain the indicator $G$, their ratios have relation between the economic and financial positions that companies have adopted. The ratio between $\Delta \mathrm{A}$ and $\mathrm{OR}$ variables indicates how many times the OR is guaranteed with the economic assets of company. The $\Delta \mathrm{A}$ variable indicates the level of banking guaranty, so when this ratio is higher than one, the company can pay its OR with the guarantees gained from markets. The second ratio measures how many times the MS is included on increasing of financial positions of company. When this ratio is higher than one, the bank has less liquidity to cover their financial positions, and the level of guarantee is relevant in this case. Therefore, the $G$ indicator measures the kind of guaranty and the economic variations of banking company.

The above limitations of Edgeworth's box have sense by the measure criteria of indicators $L$ and $G$. When $L$ takes a positive value, the bank company gets credit from financial market, because investors and stakeholders trust on its management. If $L$ is negative, the company gives credit to financial market, and their economic guaranties grow to hedge its management risk. The analysis of observations by $G$ indicator has an economic significance, as it has said on above paragraph. When this indicator is positive, the company enhances its economic guaranties and the company has a high level of MS. When this indicator is negative, the company loses economic guaranties and gives credit to financial market in order to continue its activity. These measurements 


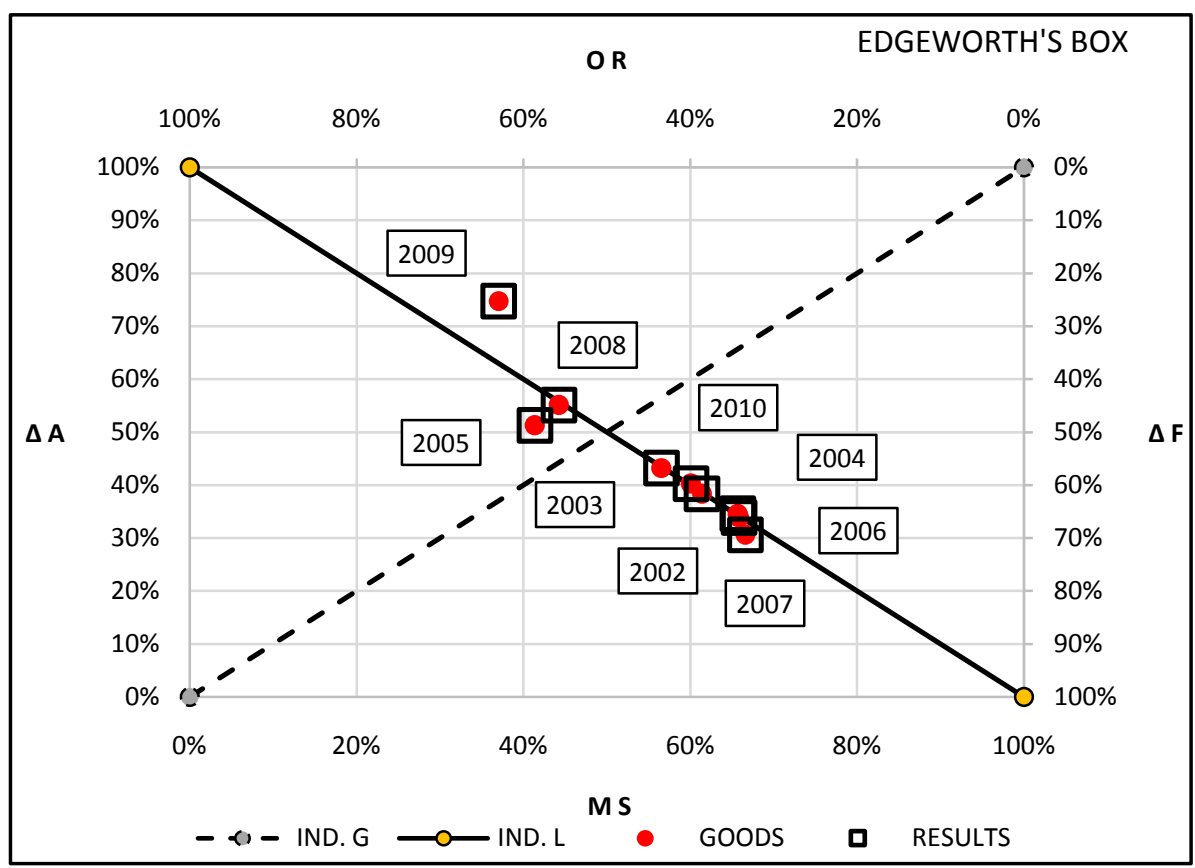

Figure 1. Edgeworth's box to Banking Company CAM.

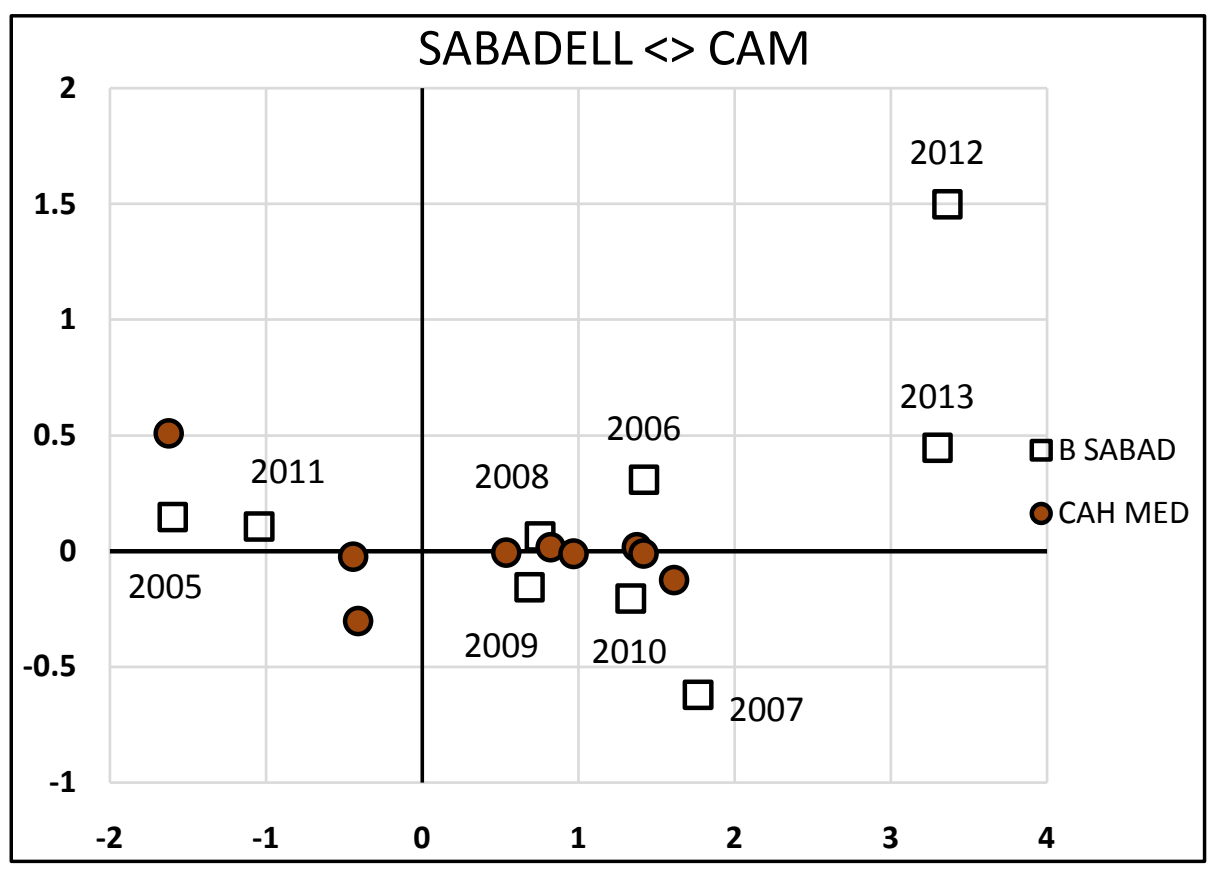

Figure 2. Edgeworth's box (2).

made by $L$ and $G$ indicators allows us to get four zones in an Edgeworth's box. The A zone is when $L$ and $G$ indicators are positive. The $\mathrm{C}$ zone is when $L$ and $G$ indicators are negative. The observation is on D zone when $L$ indicator is positive and $G$ indicator is negative and, at last, the observation is zone B when $L$ and $G$ indicators are negative and positive, respectively.

Figure 2 has the graph of Edgeworth's box to compare the two positions of Sabadell and CAM banks. The first of them absorbs the CAM bank, because its position is better than CAM bank. The CAM bank was a public bank, which has directors of management appointed by regional government. The crisis did not allow making 
decisions according the financial situation of company [16]. This financial situation is analyzed in Figure 1. The CAM bank in 2008 and 2009 years has dangerous situations. In 2008, the CAM bank was on zone C, the company gave credit to market and lost guaranties. Consequently, the market did not trust on its management and the next year, the company gave credit to markets to continue its activity and its risk increased according to the liquidity of financial market. This risk is hedged to increase the economic guaranty in 2009 year. In two years, the financial position of CAM Company did not cover its OR and its economic guaranty was higher than the MS, according to book values. These book values of assets did not according their market value, so the crisis of company was present.

The financial positions of Sabadell Bank were different in 2008 and 2009. The value of indicator $L$ was positive and its indicator $G$ had a negative position in 2009. Table 6 has the values of $L$ and $G$ indictors for two banking companies, and the zones of management to both companies. Previously to merger by absorption for Sabadell Bank, the CAM was on zones A, D, C and B from 2006 to 2009, respectively in each year of annual series. It disclosed the bad financial situation of this company. On the contrary, in these years, the Sabadell Bank always had a positive value on $L$ indicator. The management of financial crisis has been well managed by Sabadell Bank. In 2008, this banking company was on zone A, as it can see in Table 6.

The evolution of Sabadell Bank after the acquisitions of banking CAM shows that this company needs adjust its financial position in 2010 and 2011. Later Sabadell Bank improves its positions, because in 2012 and 2013 it gets on zone A in Edegeworth's box in Figure 2. Comparing its activity respect to listed companies in Table 6, it allows confirming this opinion. In 2010 and 2011, the listed companies on IBEX 35 take positions on A zone, and in 2013 the listed companies get the D zone. Nevertheless, Sabadell Bank gets positions on A zone in Edgeworth's box for the last year in Figure 2.

The evolutions of banking companies of Table 6 are in Figure 3. The dashed lines represent the evolution of behavior of $G$ indicators and the continued lines are evolutions of $L$ indicators. The black lines represent the behavior of banking company CAM, and this bank got the worst position of listed companies (LC) on IBEX 35 in the year of 2009. Nevertheless, the evolution of Sabadell Bank (SB) is better than that of CAM, but it is the same of listed companies. The acquisition of the CAM by for Sabadell Bank had its effect in 2011. The Sabadell Bank lost its financial positions compared to listed companies, but in 2013 it achieved a better position of listed companies.

\section{The General Analysis of Bank Companies Listed in IBEX 35}

Finally, to prove the validity of AMEB methodology, indictors $L$ and $G$ of listed companies on IBEX 35 have the same evolution of monetary indicators on graphs in Figure 4 and Figure 5. Before to comment the evolution

Table 6. The value of $L$ and $G$ indicators for CAM and Sabadell.

\begin{tabular}{ccccccccccc}
\hline CAM & 2010 & 2009 & 2008 & 2007 & 2006 & 2005 & 2004 & 2003 & 2002 \\
\hline Zone & $\mathrm{D}$ & $\mathrm{B}$ & $\mathrm{C}$ & $\mathrm{D}$ & $\mathrm{A}$ & $\mathrm{C}$ & $\mathrm{D}$ & $\mathrm{A}$ & $\mathrm{D}$ \\
L (CAM) (a) & 0.538 & -1.624 & -0.442 & 1.613 & 1.375 & -0.412 & 1.419 & 0.823 & 0.969 \\
G (CAM) (a) & -0.007 & 0.508 & -0.024 & -0.125 & 0.016 & -0.302 & -0.010 & 0.017 & -0.011 \\
\hline Sabadell & 2013 & 2012 & 2011 & 2010 & 2009 & 2008 & 2007 & 2006 & 2005 \\
\hline Zone & $\mathrm{A}$ & $\mathrm{A}$ & $\mathrm{B}$ & $\mathrm{D}$ & $\mathrm{D}$ & $\mathrm{A}$ & $\mathrm{D}$ & $\mathrm{A}$ & $\mathrm{B}$ \\
L (BS) (a) & 3.299 & 3.362 & -1.044 & 1.335 & 0.687 & 0.755 & 1.766 & 1.420 & -1.597 \\
G (BS) (a) & 0.445 & 1.498 & 0.105 & -0.206 & -0.158 & 0.063 & -0.622 & 0.307 & 0.147 \\
\hline Listed Companies & 2013 & 2012 & 2011 & 2010 & 2009 & 2008 & 2007 & 2006 & 2005 \\
\hline Zone & $\mathrm{D}$ & $\mathrm{A}$ & $\mathrm{A}$ & $\mathrm{A}$ & $\mathrm{D}$ & $\mathrm{D}$ & $\mathrm{A}$ & $\mathrm{D}$ & $\mathrm{B}$ \\
\hline (LC) (a) & 0.457 & 1.786 & 2.718 & 2.804 & 1.583 & 1.445 & 1.936 & 1.404 & -0.498 \\
G (LC) (a) & -2.214 & 0.574 & 0.543 & 0.531 & -0.353 & -0.835 & 0.526 & -0.078 & 0.030 \\
\hline
\end{tabular}

a. The variables $L$ and $G$ to companies of table are to CAM, $L$ (CAM) and $G$ (CAM); to Sabadell Bank, $L$ (BS) and $G$ (BS); to listed companies of IBEX 35 are $L$ (LC) and $G(\mathrm{LC})$. 


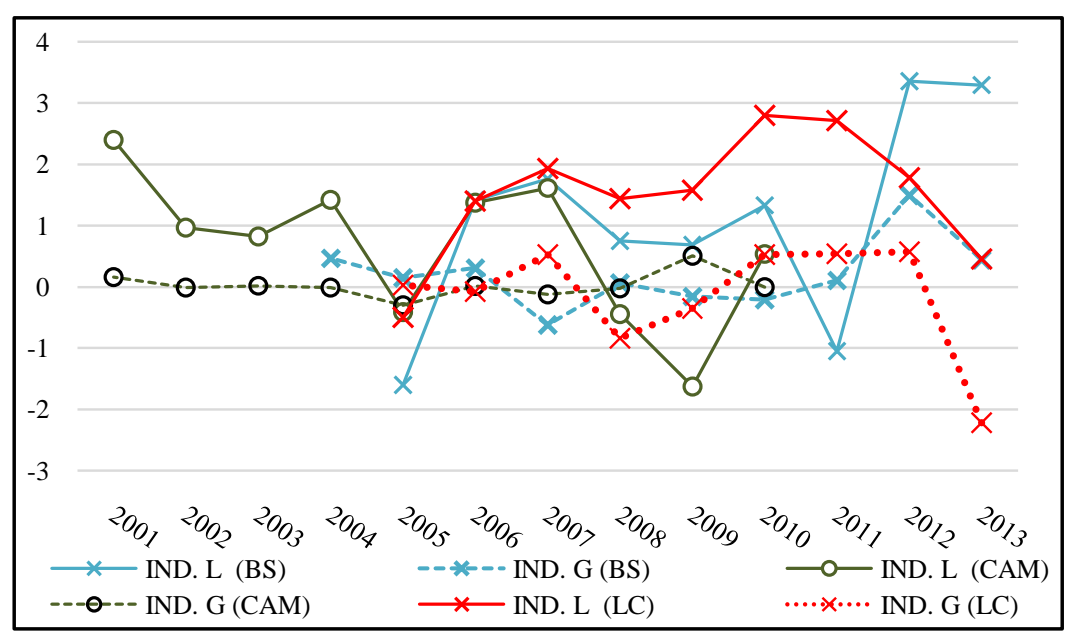

Figure 3. Evolution of Listed Companies, CAM and Sabadell Bank.

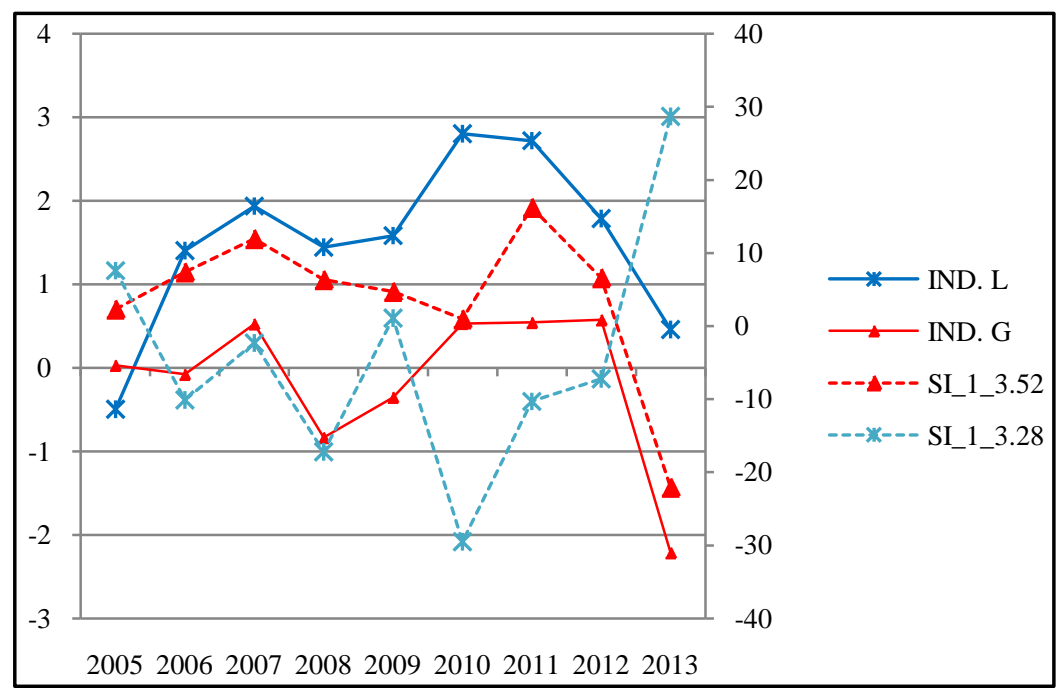

Figure 4. Evolution of $L$ and $G$ indicators of Listed Companies.

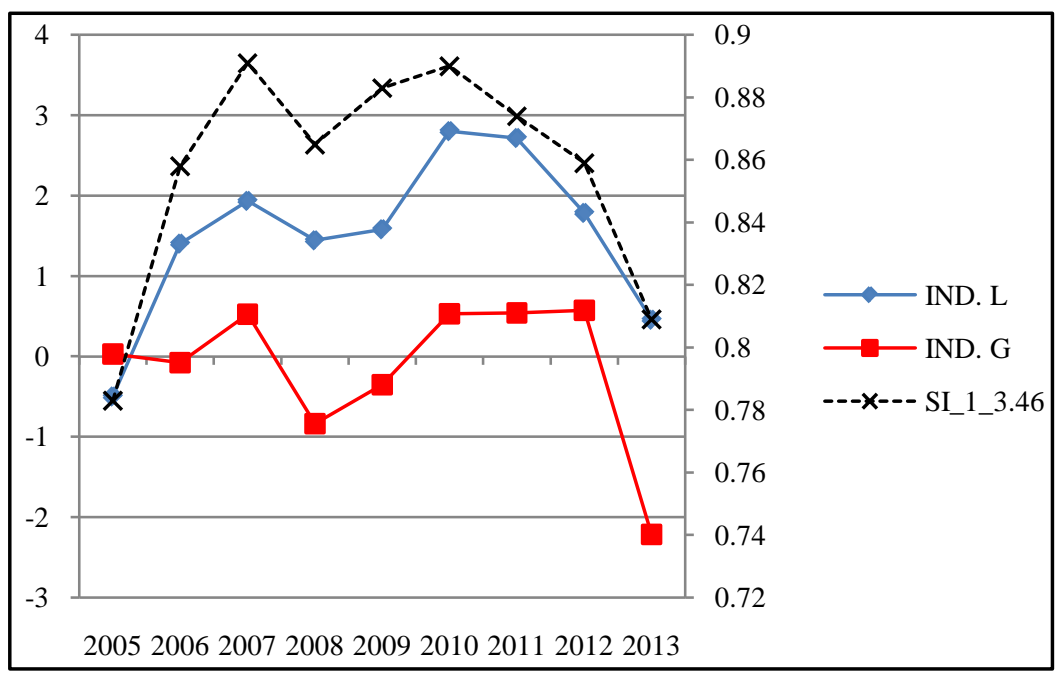

Figure 5. Evolution of $L$ and $G$ indicators of Listed Companies household debts. 
of listed companies, it needs to remember that the $L$ indicator gives a vision of financial positions of the company. When the $L$ indicator is positive, the bank company has the trust of market, and when $G$ indicator is positive, the company manages correctly its positions of guaranties. According to these measures, the banking companies have problems in 2008, 2009 and 2013. On these last positions, the indicator $G$ took a negative value, and $L$ indicator decreased. Therefore, companies lost the trust of financial market and the level of guaranties decreased, too. The answer of financial market is measured by monetary variables such as differences between liabilities, less assets of derivatives (SI_1_3.52), interannual variation rate of investment funds bond in Euros (SI_1_3.28) and percent of GDP (SI_1_3.46) of household debt and NPI. All variables are series obtained from Bank of Spain, and their evolutions are in Figure 4 and Figure 5.

The evolution of financial variables and of the $G$ and $L$ indicators is analyzed in Figure 4. These indicators have linear correlations with evolution of derivatives and investment funds bonds, respectively, and both fulfill null hypothesis, according to the result of Table 7. The behaviors of listed companies have influence on behavior of derivatives and investment funds bond, but $L$ and $G$ indicators are independents, so that they measure different things. In Figure 4, there is a change of tendency in 2009 between $G$ indicator and the derivatives (SI 1_3_52). These differences of behavior continued until 2011. On the contrary, the change of tendency between $L$ indicator and investment on bonds began in 2010, and it continued to end of the period. The change of tendency of derivatives shows perturbations in financial market, the change of guaranty is different respect to the previous period. In the next year 2010, the rate of interannual variation on investment funds bond (SI_1_3.28) decreased, taking negative value, but $G$ and $L$ indicators had the same tendency, so markets had trust on activity of banking listed companies. In the next years, the market did not trust on management of company and the rate (SI_1_3.28) increased. According to results of Table 7, indicator $G$ and $L$ announced the financial crisis in 2006, when $G$ indicator had a negative value. Later, in 2008, 2009 and 2013, the $G$ indicator had negatives values, and the listed companies had problems on their management [16]-[19].

The statistic series of household debt with relation of GDP explains the behavior of listed bank companies. This series has a high level of correlation with $L$ indicator and do not fulfill null hypothesis, as the information in Table 8 suggests. This series (SI_1_3.46) is represented on graphic 8 and its behavior presents a new situation of difficulties in 2013. The financial position in 2013 has a worse position than previous years. This situation is according to the comments of economic perspectives of Spain on the financial stability report of May 2014 of Bank of Spain, on pages 11 and 12 respect to evolution of credit and the environment financial. However, given that euro area financial markets have not yet fully normalized and in light of the still-incipient economic recovery, the picture remains difficult for the banking sector; factors of pressure on banks' income statements persist and advise they persevere with strengthening their operational efficiency and the conservation

Table 7. The evaluation of indicators $L$ and $G$ in Figure 4.

\begin{tabular}{|c|c|c|c|c|c|c|}
\hline Variables (c) & IND.G (a) & SI_1_3.52 (b) & IND. $L$ (a) & SI_1_3.28 (b) & IND. $L$ & IND. $G$ \\
\hline Mean & -0.1419 & 3.82411 & 1.51494 & -4.3556 & 1.51494 & -0.141902 \\
\hline Variance & 0.84178 & 115.878 & 1.06893 & 267.905 & 1.06893 & 0.841784 \\
\hline Observations & 9 & 9 & 9 & 9 & 9 & 9 \\
\hline Coefficient of correlation of Pearson & 0.83057 & & -0.71346 & & 0.53242 & \\
\hline Hypothetic differences of means & 0 & & 0 & & 0 & \\
\hline Degree of freedom & 8 & & 8 & & 8 & \\
\hline Statistical t & -1.1879 & & 1.02866 & & 5.23757 & \\
\hline $\mathrm{P}(\mathrm{T} \leq \mathrm{t})$ one-tail & 0.13446 & & 0.16686 & & 0.00039 & \\
\hline critical value of the $t$ (one tail) & 1.85954 & & 1.85955 & & 1.85955 & \\
\hline $\mathrm{P}(\mathrm{T} \leq \mathrm{t})$ two-tails & 0.26892 & & 0.33373 & & 0.00078 & \\
\hline Critical value of the $t$ (two-tailed) & 2.30600 & & 2.30600 & & 2.30600 & \\
\hline
\end{tabular}

a. The variables $L$ and $G$ from database ORBIS by own elaboration; b. Series SI_1_3.52 National financial account of balance of payments, derivatives and other investments (liabilities-assets), and SI_1_3.28 National financial magnitudes, financial assets of non-financial corporations and households and NPI, investment funds bond in Euros, rate interannual variation obtained from Bank of Spain; c. Level of confidence 5\%. 
Table 8. The evaluation of $L$ and $G$ indicators in Figure 5.

\begin{tabular}{|c|c|c|c|c|}
\hline & IND. $L$ (a) & SI_1_3.46 (b) & IND. $G$ (a) & SI_1_3.46 (b) \\
\hline Mean & 1.51494411 & 0.85688889 & -0.14190238 & 0.85688889 \\
\hline Variance & 1.06892867 & 0.00138236 & 0.84178398 & 0.00138236 \\
\hline Observations & 9 & 9 & 9 & 9 \\
\hline Coefficient of correlation of Pearson & 0.90606337 & & 0.49021381 & \\
\hline Hypothetic differences of means & 0 & & 0 & \\
\hline Degree of freedom & 8 & & 8 & \\
\hline Statistic t & 1.9735218 & & -3.32987632 & \\
\hline $\mathrm{P}(\mathrm{T} \leq \mathrm{t})$ a tail & 0.0419427 & & 0.00519316 & \\
\hline Critic value of $\mathrm{t}$ (a tail) & 1.85954804 & & 1.85954804 & \\
\hline $\mathrm{P}(\mathrm{T} \leq \mathrm{t})$ two tails & 0.08388539 & & 0.01038631 & \\
\hline Critic value of $t$ (two tails) & 2.30600414 & & 2.30600414 & \\
\hline
\end{tabular}

a. The variables $L$ and $G$ from database ORBIS by own elaboration; b. Series SI_1_3.46 Quarterly financial accounts, Household debt and NPI, Percent of GDP, obtained from Bank of Spain.

of their capital [20].

\section{Conclusion}

The actual financial crisis has led the making decisions according to indicators generated from international authorities, but following criteria of monetary theory. The different opinions of economists to overcome this financial crisis have cushioned their capacity to explain how economic equilibrium can achieve. At the same time, the demand of international authorities to apply the accrual criterion and the method of double entry on accounting systems, in order to obtain standard information from economic subjects, suggest applying the same criteria to measure the economic and financial activity of any kind of company. In this context, the manuscript measures the equilibriums of bank companies listed in IBEX 35 and evaluates their management in the period of Spanish financial crisis. The aim of this manuscript is to show the explanatory capacity of AMEB only, and thus the behaviors of their two indicators are contrasted with general variables of monetary politic. This last information obtained from databases of Bank of Spain is contrasted with information of European Commission and European Central Bank to get an objective opinion of financial crisis in Spain. In short, the AMEB analyzes the equilibrium of banks companies by two kinds of indicators, which measure their economic and financial decisions. These indicators have been contrasted with financial variables of Spanish economy to prove their explicative capacity on banking activity. The main aim of this manuscript is to present a same methodology to explain the management activity of financial and non-financial companies. Therefore, the AMEB allows researchers to know the effects of economic and monetary measures issued for a government authority on two kinds of companies.

\section{References}

[1] Shrieves, R.E. and Dahl, D. (1992) The Relationship between Risk and Capital in Commercial Banks. Journal of Banking \& Finance, 16, 439-457. http://dx.doi.org/10.1016/0378-4266(92)90024-T

[2] Ellul, A. and Yerramilli, V. (2013) Stronger Risk Controls, Lower Risk: Evidence from U.S. Bank Holding Companies. The Journal of Finance, 68, 1757-1803. http://dx.doi.org/10.1111/jofi.12057

[3] Javaid, S., Anwar, J., Zaman, K. and Gafoor, A. (2011) Determinants of Bank Profitability in Pakistan: Internal Factor Analysis. Mediterranean Journal of Social Sciences, 2, 59-78.

[4] Cosimano, T.F. and Hakura, D.S. (2011) Bank Behavior in Response to Basel III: A Cross-Country Analysis. International Monetary Fund, Working Paper WP/11/119.

http://www.aitomo.it/montanaro/bibliogestione/IMFwp11119_Bank\%20behavior\%20in\%20response\%20to\%20Basel \%20III.pdf

[5] Bertrand, M., Duflo, E. and Mullainathan, S. (2002) How Much Should We Trust Differences-in-Differences Estimates? National Bureau of Economic Research, Working Paper No. 8841. 
[6] Abadie, A. (2005) Semiparametric Difference-in-Differences Estimators. Review of Economic Studies, 72, 1-19. http://dx.doi.org/10.1111/0034-6527.00321

[7] Angrist, J.D., Jordà, O. and Kuersteiner, G.M. (2013) Semiparametric Estimates of Monetary Policy Effects: String Theory Revisited. Federal Reserve Bank of San Francisco, Working Paper 2013-24. http://www.frbsf.org/economic-research/files/wp2013-24.pdf.

[8] Aysan, A.F., Ertek, G. and Öztürk, S. (2011) Assessing the Adverse Effects of Interbank Funds on Bank Efficiency through Using Semiparametric and Nonparametric Methods. In: Fethi, M.D., Gaganis, C., Pasiouras, F. and Zopounidis, C., Eds., Financial Services: Efficiency and Risk Management (Studies in Financial Optimization and Risk Management), Nova Science Pub Inc., Hauppauge. http://research.sabanciuniv.edu

[9] Haimila, K., Penttilä, A., Arvola, A., Auvinen, M.K. and Korhonen, M. (2012) Analysis of the Adequate Size of a Cord Blood Bank and Comparison of HLA Haplotype Distributions between Four Populations. Human Immunology, 74, 189-195.

[10] Bassett, W.F., Chosak, M.B., Driscoll, J.C. and Zakrajšek, E. (2013) Changes in Bank Lending Standards and the Macroeconomy. Finance and Economics Discussion Series. Divisions of Research \& Statistics and Monetary Affairs, Federal Reserve Board, Washington DC and (2014) Journal of Monetary Economics, 62, 23-40. http://dx.doi.org/10.1016/j.jmoneco.2013.12.005

[11] Krause, J. and Paolella, M.S. (2014) A Fast, Accurate Method for Value-at-Risk and Expected Shortfall. Econometrics, 2, 98-122. http://dx.doi.org/10.3390/econometrics2020098

[12] Bundock, B., Malloch, T. and Thornton, J. (2010) Environmental and Social Transparency under the Companies Act 2006: Digging Deeper. http://www.clientearth.org/

[13] European Parliament (2003) Directive 2003/51/EC of the European Parliament and of the Council of 18 June 2003 Amending Directives 78/660/EEC, 83/349/EEC, 86/635/EEC and 91/674/EEC on the Annual and Consolidated Accounts of Certain Types of Companies, Banks and Other Financial Institutions and Insurance Undertakings.

[14] Draft Regulations Laid Before Parliament under Sections 473(3), 1290 and 1292(4) of the Companies Act 2006, for Approval by Resolution of Each House of Parliament. Draft Statutory Instruments. 2013 No. XXXX. Companies. The Companies Act 2006 (Strategic Report and Directors’ Report) Regulations 2013. https://www.gov.uk/government/uploads/system/uploads/attachment_data/file/206241/bis-13-889-companies-act-2006 -draft-strategic-and-directors-report-regulations-2013.pdf.

[15] Perez Benedito, M.A. (2014) Accounting Analysis of Economic Policy of Spain (2012). Theoretical Economics Letters, 4, 254-261. http://dx.doi.org/10.4236/tel.2014.43035

[16] European Commission (2008) Communication from the Commission on the Application of State Aid Rules to Measures Taken in Relation to Financial Institutions in the Context of the Current Global Financial Crisis. Official Journal of the European Union, C 270/02 of 25.10.2008, 8 (The Banking Communication).

[17] European Commission (2011) Communication from the Commission on the Application, from 1 January 2011, of State aid Rules to Support Measures in Favour of Banks in the Context of the Financial Crisis. Official Journal of the European Union, 2010/C 329/07.

[18] European Commission (2013) Information from European Union Institutions, Bodies, Offices and Agencies. Official Journal of the European Union, 2013/C 216/01.

[19] European Central Bank (2014) Decision of the European Central Bank of 26 September 2013on Additional Measures Relating to Euro System Refinancing Operations and Eligibility of Collateral (ECB/2013/35). Official Journal of the European Union, 2013/645/EU.

[20] Bank of Spain (2014) Financial Stability Report, 5/2014. http://www.bde.es 
Scientific Research Publishing (SCIRP) is one of the largest Open Access journal publishers. It is currently publishing more than 200 open access, online, peer-reviewed journals covering a wide range of academic disciplines. SCIRP serves the worldwide academic communities and contributes to the progress and application of science with its publication.

Other selected journals from SCIRP are listed as below. Submit your manuscript to us via either submit@scirp.org or Online Submission Portal.
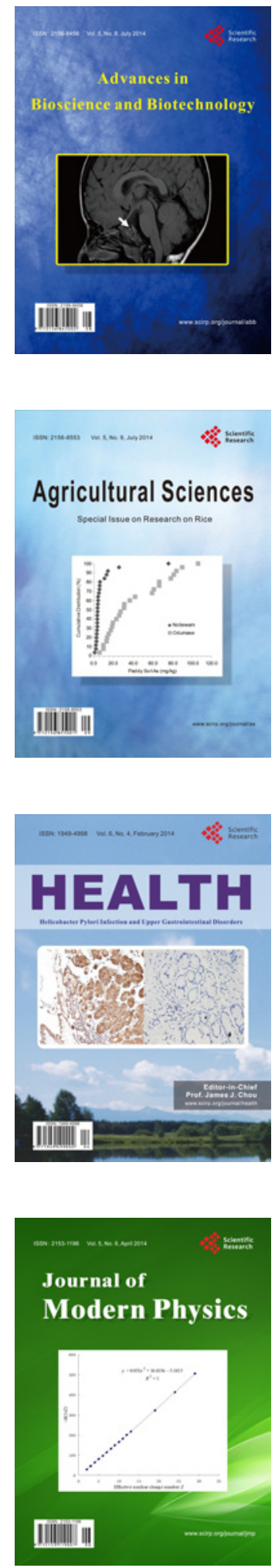
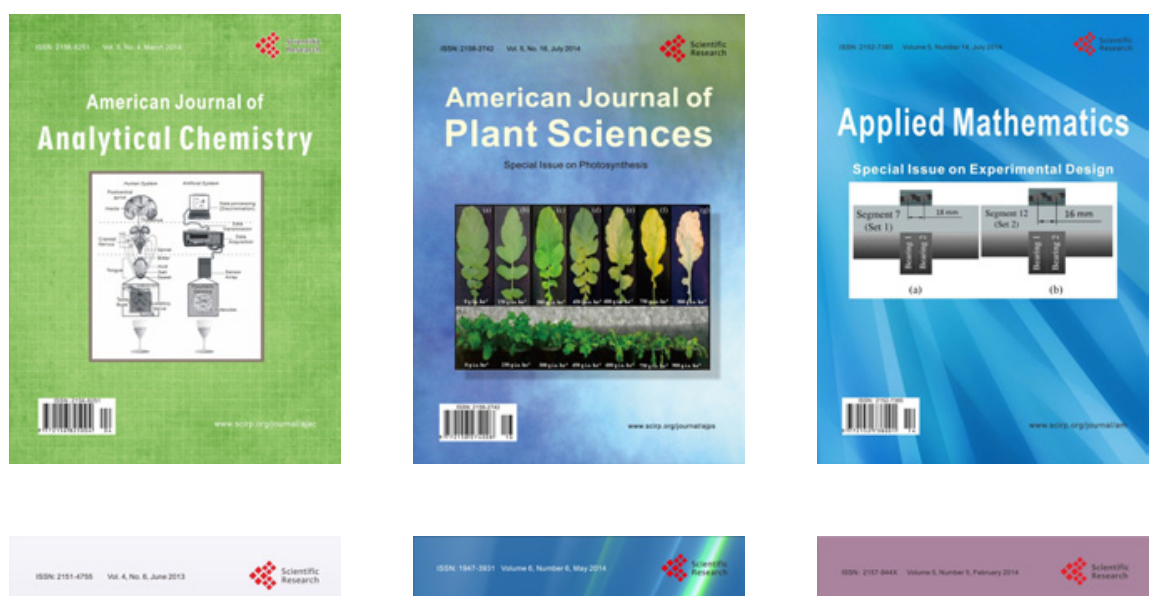

Creative Education
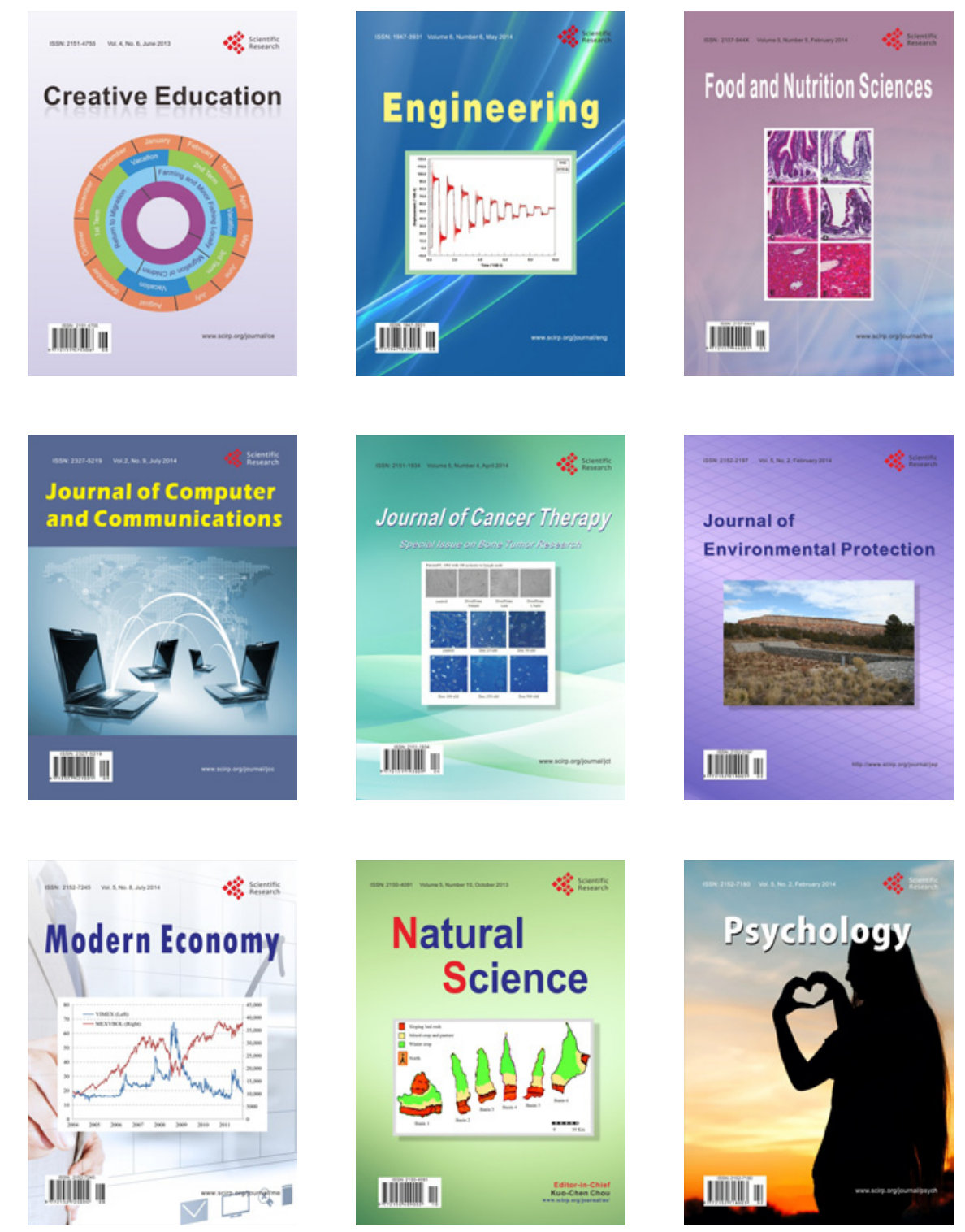